\title{
EFFECT OF DIFFERENTIATION STRATEGY ON PERFORMANCE OF SELECTED SMALL SCALE MANUFACTURING FIRMS IN NIGERIA
}

\author{
${ }^{1}$ ELIKWU, Michael Ikechukwu and ${ }^{2}$ Mohammed, Munirat Nma \\ ${ }^{1}$ Department of Entrepreneurial Studies, Michael Okpara University of Agriculture, Umudike, Abia State, \\ Nigeria \\ ${ }^{2}$ Department of Business Administration \& Management, Federal Polytechnic Nasarawa, Nasarawa State
}

DOI: 10.46609/IJSSER.2020.v05i08.004 URL: https://doi.org/10.46609/IJSSER.2020.v05i08.004

\begin{abstract}
Currently, most manufacturing firms in Nigeria are operating within a highly dynamic business environment considered harsh and fiercely competitive, owing to diverse factors such as saturated market for consumable goods, unfair competitive advantage in favour of multinational manufacturing firms with enormous resources and increasing industry competition. This implies that small manufacturing firms are in dire need of innovative strategies to enhance their competitiveness and performance; hence, the need to determine the effect of differentiation strategy on performance of selected small manufacturing firms in Nigeria, with specific objectives on effect of product, package and channel differentiation on sales performance, product acceptability and product availability. This study employed the cross-sectional survey research design to collect primary data from a sample size of 193 respondents. The purposivestratified sampling was adopted to select indigenous small manufacturing firms, while the random sampling was used to administer the research instrument. The research instrument was subjected to content and construct validity, while the reliability of the instrument was tested using the Cronbach Alpha, which gave a value of 0.78. Using the simple frequency tables to analyse data and single regression to test postulated hypotheses; the findings showed that, with a consistent result of 0.413 , product differentiation has a positive relationship and significant effect on sales performance; product package differentiation has a positive relationship and significant effect on customer acceptability based on a consistent result of 0.437 , while channel differentiation has a positive relationship and a significant effect on product availability based on a consistent result of 0.423 . The study recommended that, management of small manufacturing
\end{abstract}




\section{International Journal of Social Science and Economic Research}

ISSN: $2455-8834$

Volume:05, Issue:08 "August 2020"

should make efforts to enhance the quality of their products to global standard; should enhance the present quality, durability, design and features of the product packages to influence consumers' acceptability; and strengthen the product supplies to target markets through the differentiated channels.

Keywords: Acceptability, Availability, Channel, Differentiation, Packaging, Product-Quality

\subsection{Introduction}

The global business environment over the last two decades has been characterised by innovative changes associated with strategic management practices, creating new opportunities (Aremu, Aremu \& Olodo, 2015) and enhancing competitive capabilities to influence performance and growth of various business concerns, amid increasing industry and market competitiveness (Mamman, Aminu \& Adah, 2013). For firms operating within the processing and manufacturing industry, acquiring competitive advantage across core organisational functional areas is considered the current focus of firms with performance driven strategies (Mohammed \& Nzelibe, 2014). In the manufacturing industries across the globe, the success of a firm's differentiation strategies are indicators of viable innovations (Kamau, 2013), which very often leads to inflow of new entrants into the industry and increases imitations (Lynch, 2013). This affirms the assertion that regular introduction of innovative products by manufacturing firms results in the opening of different market niches (Mosey, 2009), essential for the continued existence of these firms. However, this is reliant on the capacity of the firm's differentiation strategy to successfully maintain a balance between the product's premium and its perceived unique (Slater \& Olson, 2011), which is a basis to achieve competitiveness (Acquaah \& Ardekani, 2006).

In the contemporary competitive market, firms that build distinctive and inimitable products develop competitive advantage which positions such firms for enhanced performance than competing rivals (Raduan, et al., 2009). This indicates that a firm's strategy to optimise performance can be achieved through differentiation of product(s) or services from similar ones offered by competitors, or by ensuring cost efficient manufacturing (Spencer \& Salmon, 2009). Differentiation strategies adopted by firms' are often focused on offering customers unique products and value different from that of competitors (Okeke \& Ugwuegbu, 2018). The dominant perception behind a differentiation strategy is customers' preparedness to pay more for the perceived value offered in the product that differentiates it from that of competitors (Dirisu, Iyiola \& Ibidunni, 2013). However, regardless of the differentiation strategy adopted by firms, the strategy should be based on customers' needs and the competitor's core competence (Hitt, Ireland \& Hoskisson, 2012). Differentiation is a strategy which seeks to provide products or services with inimitable or better benefits widely valued by buyers than that of a firm's 


\section{International Journal of Social Science and Economic Research}

ISSN: $2455-8834$

Volume:05, Issue:08 "August 2020"

competitors' and central to a firm gaining competitive advantage (Johnson, Scholes \& Whittington, 2008). In adopting a differentiation strategy, firms are faced with product, price, channel, variety and package (image) differentiation strategies (Kotler \& Keller, 2014). However, this study examined focused on how product-quality, package and channel differentiation strategies affects performance of selected small manufacturing firms in Nigeria.

\subsection{Product Differentiation}

This concept entails measures taken to distinguish a product from other competing products or from other products offered by same firm; which involves distinguishing the quality of such products in terms of its physical features, functions or durability for an identified market segment (Anderson, De Palma \& Thisse, 2012). Product differentiation also involves strategies adopted by firms to sway consumers' product choice (Dirisu, et al., 2013), which are perceived to have value added and attributes needed by consumers (Amar, 2016); hence, considered to be of value and unique compared to other similar products (Porter 1985).

Differentiating products as a firm strategy enhances the ability of firms to self-insulate from fierce competitive rivals within the industry (Jeff, 2009). This implies that product differentiation excludes firms from possible adverse price wars with industry competitors (Adewale, Adesola \& Oyewale, 2013), but supports the carving out of a niche within same industry by the firm (Ardjouman \& Asma, 2015). This makes loyal consumers insensitive to price increase at the instance of product differentiation owing to the perceived value of the brand (Nyaupane \& Gillespie, 2010), while satisfaction derived from value added in such products often results to increase in demand within the niche market where value is associated with increased price (Jeff, 2009). Increase in firm's market share has also been attributed to quality differentiation of products, as perceived quality often boosts brand and firm reputations (Davcik \& Sharma, 2015) and stimulates demand for the product (Reitsperger, 2013). Furthermore, differentiating product quality strengthens the brand's loyalty base (Ardjouman \& Asma, 2015), which becomes a barrier for likely new industry entrants, as they will fiercely compete with reputable brands for market share (Dzisi \& Ofosu, 2014).

\subsection{Product Package Differentiation}

Packaging as an extrinsic feature of a product is perceived as the noticeable appearance of a products protective pack, encompassing its categorisation, design, colour and shape, materials and other attractive characteristics (Yaro, 2015). Packaging encompasses the design and production of packs for promoting, identifying, storing and protecting products (Grundey, 2010). The concept packaging is broadly categorised according to its features, types and functions. While Copley (2004) categorised packaging as waste and convenience packages, Kotler (2002) 


\section{International Journal of Social Science and Economic Research}

ISSN: $2455-8834$

Volume:05, Issue:08 "August 2020"

categorised packaging as primary, secondary and distribution packages. Packages used for products functions in multiple dimensions, which includes protecting products from harsh weather conditions (Hong \& Suhua, 2011); providing physical protection of goods from damage or dents (Alervall \& Saied, 2013); marketing of products for identification and consumers' buying decision (Chandon, 2013); conveying messages of product usage, reusing and discarding information (Ambrose \& Harris, 2011); for effective control and appropriate transportation (Twede, 2012); theft reduction (Twede, 2012); and security from proliferation (Hong \& Suhua, 2011).

Primary package denotes the main pack which houses the product for protection, storage and for inventory purposes (Kotler, 2002); as product promotional tools and brand recognition (Heiniö, 2010). Secondary package on the other hand denotes the packs used for brand marketing and promotional purposes (Alervall \& Saied, 2013, Kotler, 2002). Furthermore, distribution package represents all sizes and types of packs (Karsh, 2011) needed for product convenience, safety during distribution of the goods (Kotler, 2002). The main features of packages used by manufacturing firms to realise packaging differentiation entail improved size, colour, shape, brand mark and material (Kotler et al., 2008). These features are important to support firms in positioning their products through attractive and distinct packaging (Copley, 2004). Therefore, packaging as a differentiation strategy helps manufacturing firms align product value with target customers' values to influence consumers buying behaviour (Hasslinger, Hodzic \& Obazo, 2013).

\subsection{Channel Differentiation}

Distribution channels employed by manufacturing firms entail strategies to ensure better positioning, maintain market visibility and support improved sales, considering that firm's marketing channels are characterized by different related costs (Soe, Moritaka \& Fukuda, 2015). However, distinguishing those dynamics influencing firm channel decisions along with easing of related constraints is also significant in efforts of channel differentiation to more importantly achieve visibility of its products in the market (Aremu \& Akinwamide, 2018). Channel differentiation has been variously described as different methods organisations offer their products, sell and deliver to their customers across various geographical locations (Bardhan, Sharma \& Saxena, 2012), which includes the uniqueness of the adopted channels distinctiveness in managing customers' orders (Filipe, Easingwood \& Coelho, 2003); also, as the decision and planned design of diverse channels of distribution taken to boost the presence of the firm's brand and competitive advantage (Kalubanga, et al., 2012). Although, the focus of channel differentiation centres more on distinctive product logistic management, it also provides 


\section{International Journal of Social Science and Economic Research}

ISSN: $2455-8834$

Volume:05, Issue:08 "August 2020"

opportunities for manufacturing firms to gain broad base customer patronage (Kotler \& Keller, 2014).

In adopting channel differentiation, firms consider diverse distribution strategies comprising of multiple actors, and which can broadly comprise distribution through wholesalers/ middlemen to product retailers and finally to consumers (Bardhan, et al., 2012), of which they all have obligations to fulfil, which is a basis for the effective functioning of the distribution system. The differentiation of distribution channels supports firms in ensuring products are made available to specific customer demography (Soe, et al., 2015); position brands in the market (Kotler \& Keller, 2014), and ensure customer loyalty towards the brand (Friedman \& Furley, 2009). A properly designed channel differentiation bridges gaps in availability of product information and firms' communication (Kamau, 2013), time and geographical gaps between manufactures and product end-users (Friedman \& Furley, 2009), regardless of the distance between manufacturers and consumers (Xaba \& Masuku, 2012). Benefits accruable to firms for strategic channel differentiation include enlarging customer base, supporting growth in product sales and firm performance (Friedman \& Furley, 2009), creation of multiple points from where products and services can be easily accessed (Abrahamsson \& Berge, 2005), with convenience to customers (McCalley, 2006), while firms are provided with opportunities to penetrate deeper into existing markets and expanding into new markets (Soe, et al., 2015). Notably, poorly differentiated channels can be counter-productive in terms of costs and brand positioning (Bardhan, et al., 2012).

\subsection{Product Sales Performance}

The notion of sales suggests that a manufacturing firm cannot imagine that customers can readily purchase their products uninfluenced (Kamau, 2013); this denotes that, customers will willingly purchase very few or none of the firm's product (Kotler, 2006). This necessitates all conscious and aggressive actions to push the firm's products through various means to influence highly voluminous purchases (Kamau, 2013), through significantly improved product varieties and quality, innovative package designs (Bodla \& Naeem, 2014), improved distribution channels (Adimo \& Osodo, 2017), appropriate pricing strategy (Pulaj, et al., 2015), aggressive advertising and promotional campaigns (Emokhare, Elikwu \& Igbokwe, 2017). Owing to the effect of the global pandemic, changing demographic factors and consumers' declining economic power (Guiné, 2019), manufacturing firms are constantly faced with increasing industry and market competition (Mcobrein (2019) and the herculean task of making strategic decisions to remain competitive (Yeboah, et al., 2013) and enhance sales performance. This has generated difficulty in assessing and predicting with rational precision, customers' behaviour towards buying of preferred products (Emokhare, et al., 2017). 


\section{International Journal of Social Science and Economic Research}

ISSN: $2455-8834$

Volume:05, Issue:08 "August 2020"

There is however unanimity in extant literature that firm competitive strategies such as differentiated product varieties and quality (Amar, 2016, Davcik \& Sharma, 2015), effective distribution channels (Adefulu \& Adeniran, 2019), differentiated product pricing (Munyoki \& K'Obonyo, 2015), innovative package designs (Alervall \& Saied, 2013), product innovative designs and features (Bayo-Moriones, et al., 2016), result oriented promotional strategies (Emokhare et al., 2017) and adaptive selling, brand name (Yaro, 2015) are often used to remain competitive (Pulaj, et al., 2015), strengthen firms' positions in the market (Kowo, et al., 2018) and achieve sustainable performance (Clair, 2018). Ascertaining performance of product sales requires the computation of the aggregate quantity of specific products sold within a particular operational period (Okeowo, 2017), utilising measurable outputs to determine such performance (Kamau, 2013), which considers revenue of cumulative sales (Ndubaro, 2013), value of product demands achieve (Robert \& Loice, 2014), total amount of new consumers compared to value of sales realised (Saraç, et al., 2014), and generated profit and percentage of gross profit margin realised (Banker, et al., 2014).

Sustainability of overall firm performance and growth (Gupta, 2013) is largely dependent on efficient productivity and increased profitability, which has always been the common goals of manufacturing firms (Roper, 2014), through optimal operational and sales performance (Ndubaro, 2013). These are made possible by firm's product quality (Davcik \& Sharma, 2015), adopting innovative strategies for product sales and marketing (Okeowo, 2017), channelled towards influencing consumers' buying behaviour (Hasslinger, et al., 2013).

\subsection{Customer Brand Acceptability}

The introduction of new products into existing competitive and saturated markets according to Pulaj, et al., (2015) may likely not survive owing to entry barriers and other numerous factors. However, reintroducing a known but differentiated product has the same likelihood of not performing in the competitive market, owing to prior performance of the product, consumers' perception and acceptability (Guiné, 2019). Thus, the Nigerian market is considered highly saturated and fiercely competitive for all kinds of locally manufactured consumable goods (Adewale, et al., 2013), owing to the highly import dependent nature of the Nigerian economy, thereby resulting in small manufacturing firms being challenged with the choice of enhancing product quality or adopting differentiation strategies for acceptability of their products by consumers (Aremu \& Akinwamide, 2018). Extant literature shows that in promoting and repositioning their brands in competitive markets (Guiné, 2019), manufacturing firms often adopt quality product (Liwali, 2013) and innovative package differentiation strategies (Chandon, 2013) to encourage customers' acceptance of firm's product (Bimbo, et al., 2017); channel distribution differentiation strategy (Okeke \& Ugwuegbu, 2018), directed towards ensuring availability of products (Polozani \& Vojin, 2017) in designated markets (Adefulu \& Adeniran, 


\section{International Journal of Social Science and Economic Research}

ISSN: $2455-8834$

Volume:05, Issue:08 "August 2020"

2019); and price differentiation elicit brand loyalty or consumer impulse buying (Glanz, Bader \& Iyer, 2012) and stimulate increased product sales (Guiné, 2019).

\subsection{Product Availability}

The term product availability has been various described as the chances of obtaining a choice product in saleable form at any time it is demanded (Moussaoui et al., 2016), at a reasonable quantity (Jader, 2017); it denotes the availability of demanded product or service information (Salam, Panahifar \& Byrne, 2016); also as the in-stock recorded by wholesalers or retailers often used as a benchmark for product availability (Ehrenthal \& Stolzle, 2013). Empirical studies on product availability have for some time focused on its' various characteristics, comprising reasons for product out-of-stock or product unavailability (Ehrenthal \& Stolzle, 2013), related impacts of out-of-stock (Musalem et al., 2010), and the various ways out-of-stock situations are reacted to (Zinn \& Liu, 2008). The view that product unavailability or availability as either negative or positive implies that, the accessibility to a physical product is preferred to its associated benefits (Salam, et al., 2016). Product availability is a significant feature of diverse markets, necessitating firms' decisions on channel differentiation (Yeboah, et al., 2013) and distribution strategies (Grubor, Milićević \& Djokic, 2016), towards ensuring a long term or short term availability of the firm's products in designated markets (Adefulu \& Adeniran, 2019), support the firm's response to variations in availability of substitute products (Polozani \& Vojin, 2017), and to sustain the drive to broaden the firm's customer size and their loyalty to the brand in a highly efficient manner (Hambrick, 2013).

Review of extant literature reveals that the unavailability of preferred consumable products or stock-outs in markets (Aastrup \& Kotzab, 2010), or the difficulty of consumers easily accessing their preferred consumables or brands (Jader, 2017) often results to the likelihood of consumers switching to substitute products (Polozani \& Vojin, 2017). The unavailability of a preferred fast moving consumable good (FMCG) in strategic markets perceived as being of high value (Hambrick, 2013) is most likely to result in consumers permanently switching to other more available products (Polozani \& Vojin, 2017), which makes the firm's channel differentiation ineffective and thereby negatively affects sales (Ehrenthal \& Stölzle, 2013). Thus, availability of a firm's product in designated markets (Polozani \& Vojin, 2017) is imperative to the effectiveness of a firm's channel differentiation strategy (Yeboah, et al., 2013), supporting continued access to the products, patronage, loyalty repurchase and sales performance (Kowo, et al., 2018).

\subsection{Empirical Review and Hypotheses Development}

\subsubsection{Product Differentiation and Sales Performance}




\section{International Journal of Social Science and Economic Research}

ISSN: $2455-8834$

Volume:05, Issue:08 "August 2020"

In a study conducted by Adimo (2018), the relationship existing between adopted product differentiation and the firm's performance was investigated. The researcher adopted the stratified simple random sampling technique which supported the selection of 134 participants as the sample size; analysis of collected primary data was done using descriptive statistical tools, while the Pearson correlation and single regression were utilised in the test of advanced hypotheses. The study established that, a product differentiation is positively correlated with firm performance. Harahap, et al., (2017) examined the product differentiation as it affects marketing performance of garment firms in Bandung City, using primary data, with the hypotheses tested with the multiple linear regressions. The study established that, product differentiation significantly affects the marketing performance of the garment firms in Bandung. Also, Githumbi and Ragui (2017) investigated how product and physical differentiation strategies affect performance of rice milling firms in Kenya. Adopting a sample size of 53 participants based on utilised stratified sampling method, collated primary data was validated, while descriptive and inferential statistics were utilised in data analysis and determination of existing relationship and differentiation effect on firm performance. The study established that adopted product differentiation had more effect on performances of the rice milling firms.

Atikiya, et al., (2015) conducted a study which evaluated the effect of differentiation strategies adopted on performance of Kenyan manufacturing firms. The research employed the descriptive and explanatory research designs in the collection of primary data from 131 participating firms. The researcher tested the stated hypotheses using the regression analysis and Pearson's correlation to ascertain the relationship between the variables. The study indicated that reputation of products and brands are enhanced when products are innovatively differentiated, which significantly affects firm performance, with existence of positive correlation between the variables. Also, Nolega, et al., (2015) conducted a study on product performance as an effect of adopted product differentiation strategy in Kenya. The study employed 125 participants as sample size, while the simple random sampling techniques was utilised in choosing respondents and administration of primary data research instrument. The study revealed that the firm's constant differentiation of its product resulted in significant increase of its distributors, implying that differentiated products have positive impact on firm performance.

In an earlier study conducted by Dirisu et al., (2013), the study investigated how product differentiation strategy influenced the performance of a multinational firm. Dirisu et al., (2013) adopted innovation, unique design and features, and superior quality as components of product differentiation as independent variable proxies, while growth in sales and customers' satisfaction were used as proxies for firm performance. With a randomly determined sample of 323 respondents, the survey research used supported the collection of data. The results revealed that, superior quality with product design significantly correlates with sales growth, while innovative 


\section{International Journal of Social Science and Economic Research}

ISSN: $2455-8834$

Volume:05, Issue:08 "August 2020"

products with unique features significantly correlate with customer satisfaction. From the reviewed empirical studies, evidence exists that most of the studies focused on large manufacturing firms, owing to their financial and operational capacities to remain competitive within the industry; hence, this creates a gap in empirical studies as little studies exists on product differentiation as it affects sales performance of small scale industries in Nigeria. This study therefore posits hypothesis one as:

$\mathbf{H}_{01}$ : There is no significant effect of product differentiation on sales performance of small scale manufacturing firms in Nigeria

\subsubsection{Package Differentiation and Customer Acceptability of Product}

Khuong and Tran (2018) conducted a study which evaluated product packaging effects on consumers' buying intentions. The researchers adopted a sample of 410 participants, with a quantitative research approach. The results revealed a direct and indirect association between elements of packaging and consumers' buying intentions. The results suggested the need for manufacturing firms to innovatively differentiate packages to strengthen buyers' memorability and arouse favourable responses towards the brand. Yaro (2015) conducted a study which investigated the effect of branding and packaging strategy of a Tobacco manufacturing firm in Nigeria on consumers' buying decisions. The study adopted a sample size of 60 willing participants, using the multi-stage sampling, to collect needed data. The study employed the use of descriptive statistics in analysing the primary data. The results established that consumers are influenced by attractive product package, premised on the interest of stakeholders in the role packaging plays in safe product distribution. The result also established that through packaging, consumers' feelings are provoked towards the brand. Also, in a study conducted by Kesinro, et al., (2015), which assessed the existing correlation between product packaging and loyalty of customers of consumable goods. With a sample of 2374 consumers adopted, the descriptive survey design supported collection of data, while the study carried out a correlation ( $r$ ) test and regression analysis to test the hypotheses. The findings revealed that elements of product packaging have significant influence over customers' brand loyalty.

Furthermore, Borishade, et al., (2015) conducted a study which investigated product packaging impact on purchase decision of consumers, with specific objective to determine to what extent design and product package influences consumer product awareness and experimental purchase. The regression analytical tool was used in testing stated hypotheses. The main findings indicated that, packaging elements are used among others to create customers' awareness which influences consumers product acceptability and purchase; hence, a there is positive and significant relationship between product package and purchase decision consumers. Finally, a review of the study conducted by Zekiri and Hasani (2015) on packaging elements as significant determinant 


\section{International Journal of Social Science and Economic Research}

ISSN: $2455-8834$

Volume:05, Issue:08 "August 2020"

to purchasing behaviour of consumers, premised on packaging as a brand facilitator. In analysing the collated data, Zekiri and Hasani adopted the descriptive statistics, with the use of the one sample t-test to test the stated hypotheses. The findings established that, packaging elements is a significant determinant in influencing consumer purchasing process, since they support the purchasing decision process.

From the reviewed empirical studies, there is evidence that firms are constantly taking strategic decisions and putting in place mechanisms (design and packaging strategies) to ensure continuous acceptability of their products in spite of the increasing global, industry and market competitiveness. Also, there is dearth of empirical studies on package differentiation as it affects customer acceptability of products of small scale manufacturing firms in the highly competitive Nigerian market; hence, the development of hypothesis two:

Ho2: Product package differentiation has no significant effect on customer brand acceptability

\subsubsection{Channel Differentiation and Product Availability}

A review of extant literature shows diverse empirical studies on channel differentiation, some of which include a study conducted by Mcobrein (2019), which investigated how wholesale product distribution structure determines satisfaction of customers. In particular, Mcobrein (2019) investigated the channel differentiation and distribution strategy employed for the marketing and distribution of products by Makola distributors. In achieving the specific objectives, Mcobrein (2019) adopted 20 participants as the study sample size, utilised the documentary review together with the survey research designs, which supported the collection of data for validation of the objectives. The study utilised the SPSS software to analyse data collated. The results revealed that the channel differentiation introduced in the marketing and distribution of products by Makola guarantees well-timed product availability in designated markets. The result further revealed that the introduced differentiated channel of distributions ensures that customers and other distributors derive satisfaction in the availability of products. Similarly, Adefulu and Adeniran (2019) conducted a study which evaluated the influence of adopted distribution channel strategies on marketing performance of participating firms in Lagos State, Nigeria. In achieving the broad and specific objectives, the researchers adopted the survey research design to collect needed data from 503 participants, being the sample size of the study. Respondents' data were analysed using descriptive statistical analytical tools, while inferential statistical tools (multiple linear regressions) were employed in hypotheses testing. In their findings, Adefulu and Adeniran (2019) indicated that distribution channel strategies significantly influenced marketing performance of the participating manufacturing firms. 


\section{International Journal of Social Science and Economic Research}

ISSN: $2455-8834$

Volume:05, Issue:08 "August 2020"

Adimo and Osodo (2017) in an earlier study empirically evaluated the extent adopted differentiation channel strategy affected performance of the firm under review. In achieving the main objective, Adimo and Osodo adopted 134 participants as sample size, which was determined by the stratified and simple random sampling techniques, supported by the correlational research design. In analysing the collected data, Adimo and Osodo used the descriptive statistical tools, the Pearson correlation was used to determine the relationship between the variables, while multiple regressions were adopted as inferential statistics to test the formulated hypotheses. The findings indicated that as a competitive advantage, differentiation channel strategy has a moderately significant and positive effect on the performance of the selected firm. Furthermore, earlier studies conducted by Karanja, Muathe and Thuo (2014) revealed that aside a positive correlation between the variables, firm marketing capability and adopted distribution channel strategy significantly impacts on organisational performance; while another earlier study by Ilodigwe (2011) established that, distribution channels determines market presence of the firm's products and significantly impacts on the firm's market share.

Though, these findings are broadly inconclusive premised on the fact that most of the studies revolved around telecommunication services operating firms and large multinational manufacturing firms, with only a handful revolving around small scale industries. The findings of Odigbo, Ogbidi and Ewa (2015) indicated an insignificant impact of new channel distributions on performance of farm produce in target markets. Also, a study conducted by Yeboah et al. (2013) revealed the existence of a negative relationship between adopted differentiated channel strategy and performance of products. Therefore, premised on the dearth of empirical studies relating to channel differentiation and its effects on availability of small scale manufacturing firms' products, this study posits hypothesis three as;

H03: Differentiation channels have no significant effect on availability of small manufacturing firms' products in target markets.

\subsection{Statement of the Problem}

Currently, most manufacturing firms in Nigeria irrespective of their sizes are operating within a highly dynamic business environment considered harsh and fiercely competitive, owing to diverse factors such as vast but saturated market for consumable goods, unfair competitive advantage in favour of multinational manufacturing firms with enormous resources and increasing industry competition (Chiekezie \& Elikwu, 2016). These large manufacturing firms are now venturing into businesses considered to be exclusively reserved for domestic manufacturing firms designed to stimulate economic growth and employment generation. The globalisation of manufacturing operations and markets has resulted in the exportation of variety of globally manufactured goods which has become real threats to small manufacturing firms in Nigeria as they face competition from inexpensive imported goods discouraging the demand for locally produced goods (Busari \& 


\section{International Journal of Social Science and Economic Research}

ISSN: $2455-8834$

Volume:05, Issue:08 "August 2020"

Oduwole, 2014). The Nigerian market is highly saturated with foreign products which are very visible, readily available and often more acceptable than locally manufactured goods (Oladele \& Arogundade, 2011); this denotes that the quality, packaging and distribution of the locally manufactured products are faced with diverse challenges such as fluctuating product demand and prices, low capacity utilisation, drop in output quality, dwindling brand reputation and overall poor performance. This therefore implies that small manufacturing firms are in dire need of innovative strategies to enhance their competitiveness and performance; hence, the need for small manufacturing firms in Nigeria to devise innovative strategies to increase their performance.

A review of empirical studies on differentiation strategies reveals that focus has been on differentiation strategies of multinational firms (Unilever Nigeria Plc) (Dirisu, et al., 2013), Coca Cola and Pepsi companies in Nigeria (Okeke \& Ugwuegbu, 2018) as they affect organisational performance, while Adio, Bananda and Eluka (2018) evaluated product differentiation and competitive advantage of Telecommunication firms in Nigeria. Despite these studies, there is scarcity of empirical studies on the effect differentiation strategies have on performance of selected small manufacturing firms operating in Nigeria, which implies that findings from such studies cannot be generalised to the small manufacturing firms. This creates a gap in empirical studies and knowledge, which this study aims to fill.

Hence, the broad objective of this study focused on the effect of differentiation strategy on performance of selected small manufacturing firms in Nigeria, with specific objectives which aimed to; examine the effect of product differentiation on the sales performance of manufacturing firms; determine the effect of innovative package differentiation on product acceptability; and to determine the effect of channel differentiation on increased market presence of small scale manufacturing firms' products in Nigeria.

To achieve these specific objectives, research questions were raised in line with the specific objectives.

i. What is the effect of product differentiation on the performance of manufacturing firms in Nigeria?

ii. What is the correlation between innovative package differentiation and product acceptability?

iii. What is the effect of channel differentiation on market presence of products of small manufacturing firms' in Nigeria?

\subsection{Materials and Methods}

This study is anchored on the positivism research philosophy which supports the use of scientific research methods in observing and measuring of facts without any influence from the researcher and guarantees generalising in an objective manner, the findings from the quantitative analysis 


\section{International Journal of Social Science and Economic Research}

ISSN: $2455-8834$

Volume:05, Issue:08 "August 2020"

(Saunders, Lewis \& Thornhill, 2012). This guaranteed that collected data for this study were appropriately transformed into usable operational statistics, which quantified the opinions of selected participants (Slevitch, 2011). In conducting this study, the field survey and case study strategies were adopted, related to the deductive research technique often utilised in descriptive researches (Creswell, 2014). In choosing these strategies, consideration was given to the nature of the study, which required the use of research instrument to collect primary data in line with the research questions, for analysis to achieve the specific objectives of the study (Collins, 2010), needed to validate the developed hypotheses. The study adopted the cross-sectional survey design (Creswell, 2014), which helped the quantitative depiction of research respondents' attitudes, views and trends events (Saunders, et al., 2012). Also, the correlational design was employed to evaluate with the aim of determining the relationship between differentiation strategies and the performance of selected small manufacturing firms in Abuja Nigeria.

The adopted a population of three hundred and fifty six (356) personnel, from two (2) selected indigenous small manufacturing firms. The firms were selected based on the purposive-stratified sampling. The sample size was determined using the Yamane (1967) statistical formula, which gave a baseline sample size of 188 with error limit of 5\% was determined, which was augmented by $20 \%$ to 226 , this ensured that after administration of the research instrument, the sample size remained well above the baseline sample size. After copies of the research instrument were administered, 193 copies were properly completed and returned. The structured questionnaire being the research instrument was validated using content validity, which determined the ability of the instrument to stimulate required responses and thereafter measure the collected data (Creswell, 2014). Also, the instrument was subjected to construct validity which ensured consistency of results from the indicators, with positive effects to practical applications (Humbley \& Zumbo, 1996; Creswell, 2014). In validating the research instrument, copies were given to and validated by scholars and experts in the marketing and statistics discipline. While for the predictability, consistency and accuracy, a reliability test of the study instrument was carried out using the Cronbach's Alpha, which gave an Alpha value of 0.78 .

\subsection{Data Analysis Procedure and Model Specification}

For the purpose of this study, collected primary data were collated and analysed with adopted descriptive analytical tools (pie chart and simple percentage frequency distribution tables), the data was tested to determine the normality, factor analysis and correlation were used to ascertain the relationship between the variables, while the single regression analytical tool was used in testing the developed hypotheses. Therefore, the decision rule for accepting or rejecting the null hypothesis for any of these tests is based on the Probability Value (PV). If the PV is less than 5\% 
or 0.05 (that is $\mathrm{PV}<0.05$ ), it implies that the regressor in question is statistically significant at $5 \%$ level; otherwise, it is not significant at that level.

For the purpose of this study, models were specified premised on the three hypotheses posited in this study. This numerical model was specified to empirically determine the effect of differentiation strategies on performance of small manufacturing firms in Abuja, Federal Capital Territory, Nigeria. In specifying the model, the independent variable (Differentiation strategies (DFS)) was decomposed into three (3) proxies; product differentiation (PRD) product package differentiation (PPD) and channel differentiation (CHD), while the dependent variable (small manufacturing firm performance (SMP)) was decomposed into three (3) proxies; sales performance (SAP) customer brand acceptability (CBA) and product availability (PRA).

\section{Dependent Variable}

$\mathrm{Y}=$ Small manufacturing Firms' Performance (SMP)

$(\mathrm{SMP})=\mathrm{f}(S A P, C B A, P R A)$

\section{Independent Variable}

$\mathrm{X}=$ Differentiation Strategies (DFS)

$(D F S)=f(P R D, P P D, C H D)$

The functional form of the econometric model is therefore given as:

$\mathrm{Y}=f\left(\mathrm{X}_{1}\right)$

Where, $\mathrm{Y}$ is dependent variable

$\mathrm{X}_{1}$ is independent variable or explanatory variable.

$\mathrm{f}=$ represents the functional notation.

The explicit form of the model for the three hypotheses is stated thus:

\section{Model for Hypothesis 1}

Ho1: There is no significant effect of product differentiation on sales performance of small scale manufacturing firms in Nigeria

$S A P=f(P R D)$

$S A P=\beta_{0}+\beta_{1} P R D_{1}+\mathrm{u}_{1}$

\section{Model for Hypothesis 2}

Ho2: Product package differentiation has no significant effect on customer brand acceptability

$C B A=f(P P D)$

$C B A=\beta_{0}+\beta_{1} P P D_{1}+u_{1}$

Model for Hypothesis 3 


\section{International Journal of Social Science and Economic Research}

ISSN: $2455-8834$

Volume:05, Issue:08 "August 2020"

Ho3: Differentiation channels have no significant effect on availability of small manufacturing firms' products in target markets.

$C H D=f(\mathrm{PRA})$

$C H D=\beta_{0}+\beta_{1} P R A_{1}+\mathrm{u}_{1}$

Where:

PRD $=$ Product Differentiation

PPD $=$ Product Package Differentiation

$\mathrm{CHD}=$ Channel Differentiation

$\mathrm{SAP}=$ Sales Performance

$\mathrm{CBA}=$ Customer Brand Acceptability

PRA = Product Availability

$\beta_{0}=$ Unknown constant to be estimated

$\beta_{1}=$ Unknown coefficients to be estimated

$\mathrm{Ui}=$ Error Term

$\beta_{1}>0$

The model's 'a priori expectation' is that individual proxies of the independent variable (PRD, PPD and CHD) are expected to positively correlate and have significant effect on individual proxies of the dependent variable (SAP, CBA and PRA). The mathematical expression is represented as; $\beta_{1}-\beta_{5}>0$ which denotes that a unit increase in a specific differentiation strategy will result in corresponding increase in associated performance proxy of the small manufacturing firms by a unit.

\subsection{Results and Discussions}

Analysis of collated data shows that distribution of respondents in the two selected firms according to gender orientation. The analysis indicates that the selected manufacturing firms both have 52 females representing 27\%, while males account for 141 of the total sample size, representing 73 of the entire sample size. In the distribution of respondents in the two selected firms according to the number of years they have been in the services of their respective firms. The analysis shows that 69 respondents, which represent $36 \%$ of the sample size, have been in the firms' services for less than 3 years; 56 respondents which represent $29 \%$ have been in the firms' services for between 4 and 6 years; 47 respondents which represent $24 \%$ of the sample size, have been in the firms' services for between 7 and 10 years, while 21 respondents representing only $11 \%$ of the sample size have been in the firms' services for more than 10 years. Concerning the distribution of respondents in the two selected firms according to the educational level and qualifications attained. The analysis shows that at the bottom of the educational level pyramid, 121 respondents which represent $63 \%$ of the sample size studied up to secondary 


\section{International Journal of Social Science and Economic Research}

ISSN: $2455-8834$

Volume:05, Issue:08 "August 2020"

education level; 39 respondents which represent $20 \%$ of the sample size studied up to diploma level; 27 respondents which represent $14 \%$ of the sample size studied up to degree level, while on 6 respondents representing 3\% of the sample size studied up to postgraduate level.

Analysis of respondents' opinions about the firms' sales performance premised on the choice of product quality differentiation strategy adopted by the selected firms, outlined in five statements. Concerning respondents' opinion whether the paint's market price is perceived as good value for the firms' product; the analysis shows that, 62 and 27 respondents representing $32 \%$ and $14 \%$ of the sample size respectively agreed and strongly agreed. This implies that a total of 89 respondents which represents $46 \%$ collectively agreed, as against 39\% who collectively disagreed. Concerning respondents' opinion whether customers' quality perception has increased the demand for the firms' paint; the analysis shows that a total of 87 respondents which represents a cumulative of $46 \%$ of the sample size agreed and strongly agreed, while 32 respondents which represents $17 \%$ are of the opinion that customers' quality perception to a moderate extent has increased the demand for the firm's paint. Also, concerning respondents' opinion whether distribution centres are regularly out of stock due to increasing product demand; the analysis indicates that, while 75 respondents which represent 39\% agreed, 19 respondents which represent $10 \%$ of the sample size strongly agreed. Notably, $19 \%$ of the sample size being 36 respondents is of the opinion that it is only to a moderate extent. Concerning respondents' opinion whether retailers of their paint products hike the market prices due to its increasing demand; the analysis indicates that a total of 89 respondents which represents $46 \%$ of the sample size agreed and strongly agreed, while $20 \%$ are of the opinion that the retailers to a moderate extent hike the market prices of the paint products due to increasing demand. Finally, concerning respondents' opinion whether the quality of the firms' paint has increased level of demand and customer repurchases; the findings indicates that, 67 and 24 respondents which represents $35 \%$ and $12 \%$ respectively agreed and strongly agreed, while $17 \%$ believe it is only to a moderate extent.

An analysis of respondents' opinions about product acceptability by customers premised on the choice of product package differentiation strategy adopted by the selected manufacturing firms. Concerning respondents' opinion whether labelling and adequate product information influences consumers' choices during product selection; the analysis shows that, 108 and 79 respondents representing $56 \%$ and $41 \%$ of the sample size respectively agreed and strongly agreed. This implies that a total of 187 respondents which represents $97 \%$ collectively agreed that labelling and adequate product information influences consumers' choices during product selection. Concerning respondents' opinion whether quality and durability of the package material gives consumers perception of product quality and safety; the analysis shows that a total of 191 respondents which represents a cumulative of $99 \%$ of the sample size agreed and strongly agreed 


\section{International Journal of Social Science and Economic Research}

ISSN: $2455-8834$

Volume:05, Issue:08 "August 2020"

that, the quality and durability of the package material gives consumers perception of product quality and safety. Also, concerning respondents' opinion whether the firms' package features makes it unique and attractive to influence consumers; the analysis shows that, 105 and 78 respondents representing $54 \%$ and $40 \%$ of the sample size respectively agreed and strongly agreed. This implies that a total of 183 respondents which represents $94 \%$ collectively agreed that, the firms' package features make it unique and attractive to influence consumers. Furthermore, concerning respondents' opinion whether inimitability of product package gives consumers a value perception of the brand; the analysis shows that, 106 and 83 respondents representing $55 \%$ and $43 \%$ of the sample size respectively agreed and strongly agreed. This implies that a total of 189 respondents which represents $98 \%$ collectively agreed that, inimitability of product package gives consumers a perception of the brand's value. Finally, concerning respondents' opinion whether innovative packaging influences customers' product choice and acceptability; the findings indicates that, 116 and 73 respondents which represents $60 \%$ and $38 \%$ respectively agreed and strongly agreed. This implies that a total of 189 respondents which represents $98 \%$ also collectively agreed that, innovative packaging influences customers' product choice and acceptability.

Analysis of respondents' opinions about product availability to customers premised on the channel differentiation strategy adopted by the selected firms, outlined in five statements. Concerning respondents' opinion whether the distribution strategies adopted has led to increased presence of the products in the markets; the analysis shows that, 74 and 31 respondents representing $38 \%$ and $16 \%$ of the sample size disagreed and strongly disagreed respectively. This implies that a total of 105 respondents which represents $54 \%$ collectively disagreed that with the statement. Concerning respondents' opinion whether wholesalers/distributors are regularly out of stock due to delay in supplies; the analysis shows that a total of 125 respondents which represents a cumulative of $65 \%$ of the sample size disagreed and strongly disagreed that, wholesalers/distributors are regularly out of stock due to delay in supplies. Also, concerning respondents' opinion whether increased product availability in target markets creates adequate awareness to influence consumer demand; the analysis shows that, 104 and 27 respondents representing $54 \%$ and $14 \%$ of the sample size disagreed and strongly disagreed respectively. This implies that a total of 131 respondents which represents $68 \%$ collectively disagreed that, increased product availability in target markets creates adequate awareness to influence consumer demand. Furthermore, concerning respondents' opinion whether the product can be found in every major paint dealer's shop due to the channel distribution; the analysis shows that, 67 and 37 respondents representing $35 \%$ and $17 \%$ of the sample size respectively disagreed and strongly disagreed. This implies that a total of 99 respondents which represents $52 \%$ collectively disagreed that, the product can be found in every major paint dealer's shop due to the channel distribution. Finally, concerning respondents' opinion whether the product has become a popular 
local brand among dealers and users due to effective channel distribution; the findings indicates that, 73 and 43 respondents which represents $38 \%$ and $22 \%$ of the sample size disagreed and strongly disagreed respectively. This implies that a total of 116 respondents which represents $60 \%$ collectively disagreed.

\subsection{Test of Hypotheses}

\subsubsection{Test of Hypothesis One}

$\mathbf{H}_{01}$ : There is no significant effect of product differentiation on sales performance of small scale manufacturing firms in Nigeria

Model One: $S A P=\beta_{0}+\beta_{1} P R D_{1}+\mathrm{u}_{1}$

Table 1: Regression result: Product differentiation and Sales performance

\begin{tabular}{llrrrrr} 
Model & & Unstandardized Coefficients & $\begin{array}{c}\text { Standardized } \\
\text { Coefficients } \\
\text { Beta }\end{array}$ & t & Sig. \\
\hline 1 & (Constant) & 1.327 & .593 & & 2.259 & .025 \\
& PRD & .413 & .132 & .235 & 3.497 & 013 \\
\hline
\end{tabular}

a. Dependent Variable: SAP

Source: SPSS 25.0

As shown in the above result, the consistent regression result for product differentiation effect on sales performance is 0.413 . This means that Product differentiation (PRD) has a positive and significant effect on Sales performance (SAP). It implies that increase in product differentiation (PRD), will lead to increase in the level of Sales performance (SAP). A $1 \%$ increase in the level of product differentiation (PRD) will bring about a $41.3 \%$ increase in the Sales performance (SAP). Given that product differentiation (PRD) p-value 0.013 is less than the significance level of 0.05 as shown in Table 1, we reject the null hypothesis which states that there is no significant effect of product differentiation on sales performance of small scale manufacturing firms in Nigeria, while the alternate hypothesis is accepted; concluding that, there is a significant effect of product differentiation on sales performance of small scale manufacturing firms in Nigeria.

\subsubsection{Test of Hypothesis Two}

$\mathbf{H}_{02}$ : Product package differentiation has no significant effect on customer brand acceptability

Model Two: $\quad C B A=\beta_{0}+\beta_{I} P P D_{I}+\mathrm{u}_{I}$ 
International Journal of Social Science and Economic Research

ISSN: 2455-8834

Volume:05, Issue:08 "August 2020"

Table 2: Regression result: Product package differentiation and customer brand acceptability

\begin{tabular}{llrrrrr} 
Model & & Unstandardized Coefficients & $\begin{array}{c}\text { Standardized } \\
\text { Coefficients } \\
\text { Beta }\end{array}$ & t & Sig. \\
\hline 1 & B & Std. Error & .284 & & 7.744 & .000 \\
& (Constant) & 2.201 & .053 & .454 & 7.201 & .006 \\
\hline
\end{tabular}

a. Dependent Variable: CBA

Source: SPSS 25.0

As shown in the above Table, the consistent regression result for product package differentiation effect on customer brand acceptability profit is 0.437 . This means that Product package differentiation (PPD) has a positive and significant effect on customer brand acceptability (CBA). This denotes that increase in Product package differentiation (PPD), will lead to increases the level of customer brand acceptability (CBA). A $1 \%$ increase in the level of Product package differentiation (PPD) will bring about a $43.7 \%$ increase in customer brand acceptability (CBA). Therefore, given that the p-value of Product package differentiation (PPD) is 0.006 which is less than the significant level of 0.05 as shown in Table 2, we reject the null hypothesis which asserts that, product package differentiation has no significant effect on customer brand acceptability, while the alternate hypothesis is accepted. This therefore implies that, product package differentiation has a significant effect on customer brand acceptability.

\subsubsection{Test of Hypothesis Three}

H03: Differentiation channels have no significant effect on availability of small manufacturing firms' products in target markets.

Model Three: $P R A=\beta_{0}+\beta_{1} \mathrm{CHD}_{1}+\mathrm{u}_{1}$

Table 3: Regression result: Channel differentiation and Product availability

\begin{tabular}{llrrrrr} 
Model & & Unstandardized Coefficients & $\begin{array}{c}\text { Standardized } \\
\text { Coefficients } \\
\text { Beta }\end{array}$ & T & Sig. \\
\hline 1 & B & Std. Error & .579 & & 3.940 & .000 \\
& (Constant) & 2.280 & .132 & .321 & 2.731 & .043 \\
\hline
\end{tabular}

a. Dependent Variable: PRA

Source: SPSS 25.0

As shown in the above Table, the consistent regression result for the relationship between Channel differentiation and Product availability is 0.423 . This means that Channel differentiation (CHD) has a positive and significant effect on Product availability (PRA). This denotes that increase in Channel differentiation (CHD), will lead to increases in the level of product 


\section{International Journal of Social Science and Economic Research}

ISSN: $2455-8834$

Volume:05, Issue:08 "August 2020"

availability (PRA). A $1 \%$ increase in the level of channel differentiation (CHD) will bring about a $42.3 \%$ increase in the Product Availability (PRA). Since the p-value of channel differentiation (CHD) is 0.043 which is lesser than the significance level of 0.05 as shown in Table 3 , we reject the null hypothesis which states that differentiation channels have no significant effect on availability of small manufacturing firms' products in target markets, while the alternate hypothesis is accepted, indicating that Channel differentiation has a significant effect on product availability of small scale manufacturing firms.

\subsection{Discussion of Findings}

From the test of hypothesis one, which determined the effect of product differentiation on sales performance of small scale manufacturing firms in Nigeria. The findings as shown in Table 1 showed a coefficient value of 0.413 , indicating that Product differentiation (PRD) has a positive relationship and significant effect on Sales performance (SAP); while the p-value for product differentiation (PRD) showed a value of 0.013 , which necessitated the rejection of the null hypothesis; hence, there is a significant effect of product differentiation on sales performance of small scale manufacturing firms. The result of the test of hypothesis one shows an agreement with the findings of Adimo (2018), which study established that, product differentiation is positively correlated with firm performance. The result is also in agreement with the findings of Harahap, et al., (2017), which established that, product differentiation significantly affects the marketing performance of the selected garment firms; Githumbi and Ragui (2017), of which the study established that adopted product differentiation had more effect on performances. The findings also aligns with that of Atikiya, et al., (2015), which study indicated that reputation of products and brands are enhanced when products are innovatively differentiated, which significantly affects firm performance, with existence of positive correlation between the variables; and the study of Nolega, et al., (2015), which revealed that the firm's constant differentiation of its product resulted in significant increase of its distributors, implying that differentiated products have positive impact on firm performance.

The analysis and test of hypothesis two, on the effect of product package differentiation on customer brand acceptability, as shown in Table 2 indicated that, a coefficient value of 0.437 implies Product package differentiation (PPD) has a positive relationship and significant effect on customer brand acceptability (CBA), while the p-value of 0.006 resulted in the acceptance of the alternate hypothesis, which states that product package differentiation has a significant effect on customer brand acceptability. The findings of test for hypothesis two aligns with the results of the study conducted by Khuong and Tran (2018), which revealed a direct and indirect association between elements of packaging and consumers' buying intentions; it also aligns with the findings from the study by Yaro (2015), which established that consumers are influenced by attractive product package; the findings also corroborate the result of the study conducted by Kesinro, et 


\section{International Journal of Social Science and Economic Research}

ISSN: $2455-8834$

Volume:05, Issue:08 "August 2020"

al., (2015), that elements of product packaging have significant influence over customers' brand loyalty. Furthermore, the result indicated in hypothesis two corroborates the findings of Borishade, et al., (2015), which indicated that, packaging elements are used among others to create customers' awareness which influences consumers product acceptability and purchase; hence, a there is positive and significant relationship between product package and purchase decision consumers; and finally agrees with the study of Zekiri and Hasani (2015), which established that, packaging elements is a significant determinant in influencing consumer purchasing process, since they support the purchasing decision process.

The analysis and test of hypothesis three on effect of differentiation channels on availability of small manufacturing firms' products in target markets, as shown in Table 3, indicated a coefficient value of 0.423 , which implies that Channel differentiation (CHD) has a positive relationship with product availability (PRA) and a significant effect; while the p-value of 0.043 which is lesser than the significance level of 0.05 necessitated the acceptance of the alternate hypothesis; hence, Channel differentiation has a significant effect on product availability of small scale manufacturing firms. The finding of this study corroborates the findings of Mcobrein (2019) which revealed that the channel differentiation introduced in the marketing and distribution of products by Makola guarantees well-timed product availability in designated markets. The result further revealed that the introduced differentiated channel of distributions ensures that customers and other distributors derive satisfaction in the availability of products. The finding also aligns with the studies of Adefulu and Adeniran (2019), which indicated that distribution channel strategies significantly influenced marketing performance of the participating manufacturing firms; Adimo and Osodo (2017), which indicated that as a competitive advantage, differentiation channel has a moderately significant and positive effect on the performance of the selected firm.

Furthermore, the result of hypothesis three corroborates the findings of Karanja, Muathe and Thuo (2014) which revealed that aside a positive correlation between the variables, firm marketing capability and adopted distribution channel strategy significantly impacts on organisational performance; while another earlier study by Ilodigwe (2011) established that, distribution channels determines market presence of the firm's products and significantly impacts on the firm's market share. However, the findings of hypothesis three in this study contradicts the results of Odigbo, et al., (2015) which indicated an insignificant impact of new channel distributions on performance of products in target markets; and also contradicts the coefficient results of Yeboah et al. (2013) which revealed the existence of a negative relationship between adopted differentiated channel strategy and performance of products.

\subsection{Conclusion and Recommendations}




\section{International Journal of Social Science and Economic Research}

ISSN: $2455-8834$

Volume:05, Issue:08 "August 2020"

The conclusion of this study is based on data analysis and the results of the three (3) posited hypotheses, which supported the answering of stated research questions and achieving of the specific objectives. Premised on the data collated from the two (2) selected paint manufacturing firms, the study affirms that in the course of production, the firms' ensure that possible loss of quality are eliminated at various production stages, by maintaining quality control presence through Input-Processing-Output stages to guarantee consistent product quality; thus, this value addition ensures that the product meets the minimum global quality standard before packaging and distribution. Therefore premised on the results of hypothesis one, this study concludes that product differentiation has a positive relationship and significant effect on sales performance. Hence, there is a significant effect of product differentiation on sales performance of small scale manufacturing firms.

Also, premised on the data collated from the two (2) selected paint manufacturing firms, the study affirms that, the quality of packaging by the firms are based on level of industry and market competition, which makes the firms' expressively differentiate the package design and features from those of competitors. The firms' packaging materials are considered durable and of very high quality, while the innovative and unique packaging helps consumers easily identify the product, of which the quality and durability of the package material gives consumers perception of product quality and safety, and attractive enough to influence consumers product choice and acceptability. Therefore, premised on the results of hypothesis two, this study concludes that, product package differentiation has a positive relationship and significant effect on customer brand acceptability. Hence, there is a significant effect of product package differentiation on customer brand acceptability.

Furthermore, premised on the data collated from the two (2) selected paint manufacturing firms, the study affirms that, the distribution channels in use have increased the points at which customers can access the firm's products, which ensures that wholesalers and retailers are never out-of-stock; hence, customers convenience forms basis for the firm's channel differentiation to make the products accessible and affordable. Premised on the results of hypothesis three (3), this study therefore concludes that channel differentiation has a positive relationship with product availability and also has a significant effect; hence, channel differentiation has a significant effect on product availability of small scale manufacturing firms. Finally, based on the purpose, aim and broad objective of this dissertation, this study concludes that differentiation strategy has both positive and significant effect on performance of selected small manufacturing firms in Nigeria.

It is therefore recommended that, aside the durability and quality of materials and processes in place, efforts should be made to enhance the quality of the paints to global standard, to make it more competitive. This will facilitate increased product demand by corporate construction firms and increase sales and profitability. It also recommends that firms should enhance the present 


\section{International Journal of Social Science and Economic Research}

ISSN: $2455-8834$

Volume:05, Issue:08 "August 2020"

quality, durability, design and features of the product packages, this will ensure that the products are more attractive to influence consumers' acceptability of the product and buying decision. Finally, It also recommends that, management of Zuma Paints and Neatcoat Nigeria Limited, should strengthen the product supplies to target markets through the differentiated channels, and further create more distribution channels to create more market presence for the products. This will ensure that the product is accessible by customers at every major and retail paint distributor, to further create awareness of the product in the Nigerian building materials market.

\section{References}

Acquaah, K. \& Yasai, A. (2006). Differentiation for firms to achieve competitive advantage: European Journal of Marketing, 46(11/12), 1647-1670.

Adefulu, A.D. \& Adeniran, J.A., (2019) Channel strategy and marketing performance of selected consumer goods firms in Lagos State, Nigeria: Academy of Marketing Studies Journal; 23(1), pp. $1-18,528-2678-23-1-187$

Adewale, A. G., Adesola M. A., \& Oyewale I., (2013). Impact of Marketing Strategy on Business Performance A Study of Selected Small and Medium Enterprises (Smes) In Oluyole Local Government, Ibadan, Nigeria. IOSR Journal of Business and Management 11 (4), 59-66.

Adimo, A.A. (2018) Relationship between product differentiation strategies and Organizational performance in Sameer Africa Kenya Limited: British Journal of Marketing Studies; 6(3), pp. 60-72,

Adimo, A.A. \& Osodo, O.P. (2017) The Impact of Distribution Channel Differentiation on Organizational Performance: The Case of Sameer Africa Limited in Nairobi, Kenya; International Journal of Business and Management Review, 5(2), pp. 1-11

Adio, A.I. Bananda, R.A. \& Eluka, J.C. (2018) Product Differentiation and Competitive Advantage: Evidence from the Nigerian Telecommunication Sector; International Journal of Management and Marketing Systems, 13(4), pp, 23-39

Alervall, V. \& Saied, J.S. (2013) Perspectives on the Elements of Packaging Design: A Qualitative Study on the Communication of Packaging; Blekinge Institute of Technology,

Amar, M.Y. (2016) The influence of product differentiation strategy on operational performance at Small and Medium Enterprises (SMEs) in South Sulawesi, Indonesia: Journal of Economics, Business, and Accountancy Ventura; 18(3), pg 343 - 350 


\section{International Journal of Social Science and Economic Research}

ISSN: $2455-8834$

Volume:05, Issue:08 "August 2020"

Ambrose, G. \& Harris, P. (2011) Packaging the Brand: Exploring the Relationship Between Packaging Design and Brand Identity: AVA Publishing.

Ardjouman, D. \& Asma, B. (2015). Marketing Management Strategies Affecting Performance of Small and Medium Enterprises (SMEs) in Cote d'Ivoire: International Journal of Business and Social Science. 6 (4), 141-150.

Aremu, J.O. \& Akinwamide, B. (2018). Prospects and challenges of sustainable rice production in Igbemo Ekiti, Southwest Nigeria: European Journal of Educational and Social Sciences, 3 (2), $125-143$.

Aremu, M.A. Aremu, M.A. \& Olodo, H.B. (2015) Impact of strategic management on the performance of small and medium scale enterprises (SMEs) in Nigeria: Journal of Sustainable Development in Africa; 17(1), 113 - 126

Atikiya, R., Elegwa, M. Kihoro, J.M. \& Waiganjo, E.W. (2015). Effect of Differentiation Strategy on the Performance of Manufacturing Firms in Kenya: Asian Journal of Humanities and Social Studies, 3(2).

Bardhan, D., Sharma, M. L., \& Saxena, R. (2012) Market participation behaviour of smallholder dairy farmers in Uttarakhand: A disaggregated analysis. Agricultural Economics Research Review, 25(2): 243-254

Borishade, T.T. Ogunnaike, O. Dirisu, J.F \& Onochie, M.P. (2015) Empirical study of packaging and its effect on consumer purchase decision in a food and beverages firm: European Journal of Business and Social Sciences, 3(11), P.P. 44 - 53

Busari, O.S. \& Oduwole, Y.K. (2014) Marketing Challenges and Opportunities Confronting Small Scale Businesses in Nigeria - A Lesson for Young Entrepreneur: Journal of Poverty, Investment and Development - An Open Access International Journal Vol.5, 118-125

Chandon, P. (2013) 'How Package Design and Packaged-based Marketing Claims Lead to Overeating', Applied Economic Perspectives and Policy, 35(1), pp. 1-39

Chiekezie, O.M. \& Elikwu, M.I. (2016) Knowledge Management and Production Capacity Optimization in Manufacturing Industry in Nigeria: 2016 International Conference Proceedings on "Managing Diversification for Sustainable Development in Sub-Saharan Africa, at the Nnamdi Azikiwe University, Awka, Anambra State, Nigeria, 8th - 10th November, 2016, Awka, Scoa Heritage Publishers, pg. 746 - 760 


\section{International Journal of Social Science and Economic Research}

ISSN: $2455-8834$

Volume:05, Issue:08 "August 2020"

Creswell, J. W. (2014) Research design: qualitative, quantitative and mixed methods approaches; Thousand Oaks, CA: Sage.

Davcik, N.S. \& Sharma, P. (2015), "Impact of Product Differentiation, Marketing Investments and Brand Equity on Pricing Strategies: A Brand Level Investigation", European Journal of Marketing, 49(5/6), 760-781

Dirisu, J.I. Iyiola, O. \& Ibidunni, O.S. (2013) Product Differentiation: A tool of Competitive Advantage and Optimal Organizational Performance (A Study of Unilever Nigeria Plc): European Scientific Journal December edition; 9(34), pp. 258-281

Emokhare, G. Elikwu, M.I. \& Igbokwe, A.C. (2017) Influence of Print and Electronic Advertising on Consumers of Coca Cola in Abuja; Conference Proceedings of the $3^{\text {rd }}$ International Conference on Social (Business Administration) ICSS-Africa, at the Nile University of Nigeria, Abuja, May 10 - 11, 2017, pg. 406 - 426, Online PDF Publication, https://icss.nileuniversity.edu.ng/proceedings/\#tab-id-3

Friedman, L. \& Furley, T. (2009) The Channel Advantage. US: Butterworth-Heinemann.

Githumbi, V. \& Ragui, M. (2017) Differentiation Strategy and Performance of Large Milling Factories in Kenya: Journal of Business and Management; 11(1:1), pp 9-16

Grundey, D. (2010) Functionality of Product Packaging: Surveying Consumers' Attitude Towards Selected Cosmetic Brands, Economics \& Sociology, 3(1), pp. 87-103.

Harahap, K. Raharja, S.J. Abdoellah, O.S. \& Muftiadi, A. (2017) Effect of Product Differentiation Implementation on Marketing Performance on Apparel Industry in Bandung City: Journal of Business and Management; 19(:3), pp, 41-50

Heiniö, S. (2010) Package Design as Strategic Branding: Proceedings of the 17th IAPRI World Conference on Packaging; pp, 237 - 241

Hong, Z. \& Suhua, Z. (2011) 'Discussion of packaging materials', presented at the $20112^{\text {nd }}$ International Conference on Artificial Intelligence, Management Science and Electronic Commerce (AIMSEC), pp. 6211 - 6213.

Ilodigwe, S.C. (2011) Assessment of the effectiveness of the distribution strategies of A-Z Petroleum Products Ltd: Master's Thesis, University of Nigeria

Kamau, J. (2013). Effects of differentiation strategy on sales performance in Nakuru town central Business District (Thesis). Kabarak University. 
International Journal of Social Science and Economic Research

ISSN: 2455-8834

Volume:05, Issue:08 "August 2020"

Karanja, S.C., Muathe, S.M.A., \& Thuo, J.K. (2014). The effect of marketing capability and distribution strategy on performance of MSP intermediary organisations in Nairobi, Kenya: Business Management and Strategy, 5(1), 197-211.

Karsh, J. (2011) 'Does Your Package Have a Personality?', Global Cosmetic Industry, 179(9), p. 30 .

Kesinro, O.R. Ojo, J.O. \& Akinsunmi, A.S. (2015) Effect of Product Package on Brand Involvement in Consumer Goods Markets of Lagos State Nigeria: American Journal of Marketing Research; 1(3), pp. 193-200

Kotler, P. (2002). Marketing Management. Millennium Edition. New York, Prentice-Hall, Inc.

Kotler, P., Armstrong, G., Wong, V., \& Saunders, J. (2008), Principles of Marketing, 5th European Editon, Harlow: Pearson Education Ltd.

Kotler P. \& Keller K. (2014). Marketing management. (14 ${ }^{\text {th }}$ edition). India: Prentice Education

Mcobrein, A.V. (2019) Determinants of Customer Satisfaction through Effective Wholesale Distribution System: A Survey of Distributors and Retail Outlets at Makola Market- Accra, Ghana; African Journal of Procurement, Logistics \& Supply Chain Management, 1(3), pp.18-35,

Mohammed, U.D. \& Nzelibe, C.G.O. (2014) Entrepreneurial skills and profitability of small and medium enterprises (SMEs): Resource acquisition strategies for new ventures in Nigeria; Proceedings of 25th International Business Research Conference 13 - 14 January, 2014, Taj Hotel, Cape Town, South Africa, ISBN: 978-1-922069-42-9

Nolega, K.S. Oloko, M. William, S. \& Oteki, E.B. (2015) Effects of Product Differentiation Strategies on Firm Product Performance: A Case of Kenya Seed Company (KSC), Kitale; International Journal of Novel Research in Marketing Management and Economics, 2(3), pp, 100 - 110, Available at: www.noveltyjournals.com

Nyaupane, P.N. \& Gillespie. J.M. (2010) Factors influencing producers' marketing decisions in the Louisiana Crawfish Industry, Louisiana State, University Agricultural centre, Bolton Rounge, LA

Obih, U. \& Baiyegunhi, L. (2018) Consumers' acceptability of local rice brands in Nigeria: Which marketing functions really matter? Journal of Agribusiness and Rural Development, 2(48) 2018, 183-196 


\section{International Journal of Social Science and Economic Research}

ISSN: $2455-8834$

Volume:05, Issue:08 "August 2020"

Odigbo, B.E., Ogbidi, J.B., \& Ewa, E.A. (2015). A situational analysis study of yam distribution strategies of farmers in Boki Local Government Area in Cross River State, Nigeria. Journal of Economics and Sustainable Development, 6(14), 190-201.

Okeke, O.T. \& Ugwuegbu, C.O. (2018) Differentiation strategy and Impact on Business: Strategic Journal of Business and Social Science; 1, pp, 1-20

Okeowo, F.B. (2017) Strategic management and performance of selected stone mining companies in South-West, Nigeria: Master's thesis, Babcock University, Ogun State Porter, M.E. (1980). Competitive strategy: techniques for analyzing industries and competitors. Free Press: New York

Porter, M.E (1985).Competitive Advantage: Creating and Sustaining Superior Performance, New York Free Press.

Porter, M.E. (1996). What is strategy? Holland Management Review, 51, 7-24.

Pulaj, E. Kume, V. \& Cipi, A. (2015). The Impact of Generic Competitive Strategies on Organizational Performance: The Evidence from Albanian Context. European Scientific Journal, October edition, 11(28), pp,273

Raduan, C.R., Jegak, U., Haslinda, A., \& Alimin, I.I. (2009) Management, strategic Management theories and the linkage with organisational competitive advantage from the Resource-based perspective: European Journal of Social Sciences. 11(3), 402-418

Reitsperger, W. D. (2013). Product quality and cost leadership: compatible strategies? Management International Review, 42(3), 31-49.

Robert, A \& Loice, G. (2014) The relationship between competitive strategies and firm performance: a case of mobile Telecommunication companies in Kenya: International Journal of Economics, Commerce and Management United Kingdom. 2(9), 1-15.

Salavou, H.E. (2013), Hybrid strategies in Greece: A pleasant surprise. European Business Review, vol. 25, is. 3, pp. 301-314. http://dx.doi.org/10.1108/09555341311314834.

Saraç, M., Ertan, Y. \& Yücel, E. (2014), How do business strategies predict firm performance? An investigation on Borsa Istanbul 100 Index. The Journal of Accounting and Finance, vol. 61, pp. 121-134.

Saunders, M. Lewis, P. \& Thornhill, A. (2009) Research methods for business students $5^{\text {th }}$ Ed: Prentice Hall 


\section{International Journal of Social Science and Economic Research}

ISSN: 2455-8834

Volume:05, Issue:08 "August 2020"

Shafiwu, A. B., \& Mohammed, A. (2013). The Effect of Product Differentiation on Profitability in the Petroleum Industry of Ghana. European Journal of Business and Innovation Research, $1(4), 49-65$.

Shah, S., Ahmed, A. \& Ahmad, N. (2013). Role of Packaging in Consumer Buying Behaviour: International Review of Basic and Applied Sciences, 1(2), 35-41.

Slater, S. F., Olson, E. M. \& Finnegan, C. (2011), Business strategy, marketing organization culture, and performance: Marketing Letters; 22(3), pp. 227-242. http://dx.doi.org/10.1007/s11002-010-9122-1.

Slevitch, L. (2011) 'Qualitative and quantitative methodologies compared: Ontological and epistemological perspectives', Journal of Quality Assurance in Hospitality and Tourism, 12(1), 73-81.

Soe, W.P.P. Moritaka, M. \& Fukuda, S. (2015) An Analysis of the Factors Influencing Marketing Channel Choice by Paddy Rice Farmers in Myanmar: J. Fac. Agr., Kyushu Univ., 60 (2), 535-542

Spencer, Joiner \& Suzanne-Salmon, (2009), titled 'Differentiation Strategy, Performance Measurement Systems and Organizational Performance: Evidence from Australia’ International Journal of Business, 14(1), 83-103.

Sule, J.G., Ogbadu, E., \& Achimugu, L.C. (2013). Channel Management for Household Products Companies in Nigeria. International Journal of Academic Research in Business and Social Sciences, 3(2), 37-45.

Twede, D. (2012) 'The birth of modern packaging Cartons, cans and bottles', Journal of Historical Research in Marketing, 4(2), pp. 245-272.

Uchegbulam, P., Akinyele, S. \& Ibidunni, A., (2015). Competitive strategy and performance of selected SMEs in Nigeria. In International Conference on African Development Issues: Social and Economic Models for Development Track. pp. 326-333

Wang, H., \& Wu, C. (2011). Green growth as the best choice for Chinese small and medium enterprises in sustainable development. Asian Social Science, 7(5), p81. http://dx.doi.org/10.5539/ass.v7n5p81

Wemerfelt, B. (1984) "A resource- Based View of the Firm," Strategic Management Journal, 5(2), Pp, 171-180 
Wijetunge, W.A. (2016). Service quality, competitive advantage and business performance in service providing SMEs in Sri Lanka: International Journal Scientific and Research Publications, 6(7), 720-728

Yaro, L.M. (2015) An Overview of Branding and Packaging Of a Company Product (A Case Study of British American Tobacco Company Zaria): Journal of Research \& Method in Education; 5(1:1), PP 35-49

Yeboah, A., Owusu, A., Boakye, S., \& Mensah, S. (2013). Effective distribution management-A pre-requisite for retail operations: A case study of Poku trading. European Journal of Business and Innovation Research, 1(3), 28-44.

Yoan, S.P. Sudarmiatin, F. \& Suharto, J. (2018), "Analysis of Differentiation Strategies to Create Competitive Advantages in Facing Global Markets" in The First International Research Conference on Economics and Business, KnE Social Sciences, pages 254- 269. DOI 10.18502/kss.v3i3.1888

Zamani, S., Parnell, J. A. Labbaf, H. \& O'Regan, N. (2013), Strategic change and decision making in an emerging nation: An exploratory assessment of Iranian manufacturing firms. Strategic Change, vol. 22, is. 5-6, pp. 355-370.

Zekiri, J. \& Hasani, V.V. (2015) The role and impact of the packaging effect on consumer buying behaviour: Ecoforum; 4(1), pp, 232 - 240 